\title{
The effectiveness of acupuncture point stimulation for the prevention of post-operative sore throat: a meta-analysis.
}

Abbreviated Title: Acupoint stimulation for the prevention of POST

Pin-Yu Jau, MD*, Shang-Chih Chang MD*

${ }^{*}$ Department of Chinese Medicine, Linsen Chinese Medicine and Kunming Branch, Taipei City Hospital, Taipei, Taiwan

Address correspondence to: Pin-Yu Jau, MD

Department of Chinese Medicine, Linsen Chinese Medicine and Kunming Branch, Taipei City Hospital, No. 530, Linsen N. Rd., Zhongshan Dist., Taipei City 104, Taiwan (R.O.C.). Tel: +886-2-2388-7088 \# 3809

Email: u9830032@cmu.edu.tw

Financial Disclosures: None

Conflicts of interest: None 
medRxiv preprint doi: https://doi.org/10.1101/2020.07.11.20148544; this version posted July 14,2020 . The copyright holder for this preprint (which was not certified by peer review) is the author/funder, who has granted medRxiv a license to display the preprint in perpetuity.

All rights reserved. No reuse allowed without permission.

Name: Pin-Yu Jau, MD

Contribution: This author helped with conception and design of the study; perform the literature searches, study selection, and quality assessment; extract and analyze the data; write original draft; and approve the final version of the manuscript.

Name: Shang-Chih Chang, MD

Contribution: This author helped with design of the study; perform the literature searches, study selection, and quality assessment; extract the data; revise draft; and approve the final version of the manuscript. 
medRxiv preprint doi: https://doi.org/10.1101/2020.07.11.20148544; this version posted July 14, 2020. The copyright holder for this preprint (which was not certified by peer review) is the author/funder, who has granted medRxiv a license to display the preprint in perpetuity.

\section{ABSTRACT}

Background: Enhanced recovery pathways can be further improved for postoperative sore throat (POST) which usually occurs after surgery with general anesthesia. Medications have shown some effectiveness in treating and preventing POST, but acupuncture or related techniques with better safety and less cost likely can be used as an alternative or adjuvant therapy to treat perioperative symptoms by stimulating acupuncture point (acupoint). Therefore, we aim to conduct a meta-analysis to assess whether acupoint stimulation help patients prevent or treat POST in adults undergoing tracheal intubation for general anesthesia.

Methods: Publication in PubMed, the Cochrane Central Register, ScienceDirect, and ClinicalTrial.gov were surveyed from Jan. 2000 through Jan. 2020. Studies that compared intervention between point stimulation and none or sham point stimulation, were included. Primary outcomes were the incidence and severity of POST at $24 \mathrm{~h}$. Secondary outcomes were the incidence of postoperative nausea and vomiting, choking cough, and sputum.

Results: Three randomized control trials and one comparative study involving 1358 participants were included. Compared with control, acupoint stimulation was associated with a reduced incidence (risk ratio, $0.3 ; 95 \%$ confidence interval $(\mathrm{Cl}), 0.2-0.45 ; p<0.001$ ) and severity (standardized mean difference, $-2.21 ; 95 \% \mathrm{Cl},-2.67$ to $-1.76 ; p<0.001$ ) of POST. 
medRxiv preprint doi: https://doi.org/10.1101/2020.07.11.20148544; this version posted July 14, 2020. The copyright holder for this preprint (which was not certified by peer review) is the author/funder, who has granted medRxiv a license to display the preprint in perpetuity.

All rights reserved. No reuse allowed without permission.

Secondary outcomes are also in favor of acupoint stimulation. There were no significant adverse events related to acupoint stimulation. Subgroup, the sensitivity, and the trial sequence analyses confirmed that the finding for POST was adequate.

Conclusions: Acupoint stimulation with various methods may reduce the occurrence of POST. It could be considered as one of nonpharmacological ways to prevent POST in enhanced recovery pathways. Further rigorous studies are needed to determine the effectiveness of acupoint stimulation.

\section{Keywords}

Acupuncture point, postoperative sore throat, general anesthesia, intubation complication, enhanced recovery

\section{Question:}

Can acupoint stimulation prevent postoperative sore throat after tracheal intubation?

\section{Findings:}

Acupoint stimulation by acupuncture or related techniques more significantly reduces the incidence and the severity of postoperative sore throat than non- /sham- treatment at 24 hours.

\section{Meaning:}


medRxiv preprint doi: https://doi.org/10.1101/2020.07.11.20148544; this version posted July 14,2020 . The copyright holder for this preprint (which was not certified by peer review) is the author/funder, who has granted medRxiv a license to display the preprint in perpetuity.

All rights reserved. No reuse allowed without permission.

Acupoint stimulation by acupuncture or related techniques could be an effective,

nonpharmacological approach to prevent postoperative sore throat in enhanced recovery after tracheal intubation.

\section{Glossary of Terms}

RCT: randomized controlled trial; QES: quasi-experimental study; TENS: transcutaneous electrical nerve stimulation; TEAS: transcutaneous electrical acupoint stimulation; NSL:

normal single lumen; SSL: spring single lumen; DL: double lumen; LMAS: laryngeal mask;

PP: prone position; SP: supine position; LD: lateral decubitus; LS /non-LS: laparoscopic surgery / non-laparoscopic surgery; POST: postoperative sore throat; PONV: postoperative nausea and vomiting; ERAS: Enhanced Recovery after Surgery; VAS: Visual Analogue Scale; ICU: Intensive Care Unit; PACU: post-anesthesia care unit 
medRxiv preprint doi: https://doi.org/10.1101/2020.07.11.20148544; this version posted July 14, 2020. The copyright holder for this preprint (which was not certified by peer review) is the author/funder, who has granted medRxiv a license to display the preprint in perpetuity.

\section{INTRODUCTION}

Postoperative sore throat (POST) is a common symptom caused by tracheal intubation undergoing general anesthesia ${ }^{1}$. The incidence of POST reported at university hospitals in Asia region varies from $35.7 \%$ to $57.5 \%$, and the studies show higher possibility of occurrence due to some factors, such as female, older age, higher intracuff pressure, type of airway devices, duration of anesthesia, and site of surgery ${ }^{2-4}$. Although this postoperative symptom is often considered as a minor complication, it remains one of the most patients' complaints after general anesthesia, second only to postoperative nausea and vomiting $(\mathrm{PONV})^{5}$. In the past few years, there have been some ways to improve PONV in Enhanced Recovery after Surgery (ERAS) ${ }^{6}$. POST also has a chance to persist for several days and may significantly distress to the patient during postoperative care ${ }^{7-8}$; we believe that there are rooms for improving ERAS pathways for $\mathrm{POST}^{9}$.

The etiologies of throat complication are believed to be caused by tracheal intubation that results in mucosal trauma and inflammation ${ }^{10-11}$. Several literatures suggest some medications, such as dexamethasone ${ }^{12}$, benzydamine ${ }^{13}$, corticosteroids ${ }^{14}$, lidocaine ${ }^{15}$, ketamine $^{16}$, and magnesium ${ }^{17}$, could be the effective strategies to prevent or treat POST.

In contrast to the modern treatments, acupuncture or related techniques are also used as an alternative or adjuvant therapy in perioperative time, for example, the management of postoperative pain ${ }^{18}$. Acupuncture is the medical practice to stimulate acupuncture points (acupoints) on the body with thin needle and improve health on the theory of traditional 
medRxiv preprint doi: https://doi.org/10.1101/2020.07.11.20148544; this version posted July 14, 2020. The copyright holder for this preprint (which was not certified by peer review) is the author/funder, who has granted medRxiv a license to display the preprint in perpetuity.

All rights reserved. No reuse allowed without permission.

Chinese medicine ${ }^{19}$. Its related techniques, including moxibustion, acupressure, acupoint application, electrical/laser/magnetic/ultrasonic acupuncture, transcutaneous electrical nerve/acupoint stimulation (TENS/TEAS), and bloodletting, are the same in principles but different in methods ${ }^{20-22}$. However, the effectiveness of acupoint stimulation of various methods in order to prevent or treat POST remains inconclusive. Therefore, in this paper, the presented meta-analysis aims to examine whether acupoint stimulation help patients prevent or treat POST undergoing tracheal intubation for general anesthesia. 
medRxiv preprint doi: https://doi.org/10.1101/2020.07.11.20148544; this version posted July 14, 2020. The copyright holder for this preprint (which was not certified by peer review) is the author/funder, who has granted medRxiv a license to display the preprint in perpetuity.

\section{METHODS}

The means and the reports of this systematic review followed the Cochrane Collaboration methodology ${ }^{23}$ and PRISMA statement ${ }^{24}$. The protocol is registered at PROSPERO (CRD42020177480)

\section{Eligibility criteria}

Regarding the types of studies, we enrolled randomized controlled trials or comparative experimental trials, and excluded follow-up studies, case series, and case reports. The target participants should have the following inclusion criteria: (1) adult patients had the elective surgery with general anesthesia; (2) all patients received intubation by various types of airway device. All retrieved studies were required to comprise at least two arms, one of which had an intervention with acupoints stimulation and the other of which had intervention with non- /sham- acupoints stimulation. Studies were also excluded if they had no evaluation of sore throat at $24 \mathrm{~h}$ after extubation or surgery.

\section{Search strategy}

We searched four electronic databases, including PubMed, Cochrane Central Register of Controlled Trials (CENTRAL), ScienceDirect, and ClinicalTrial.gov, in the period from January 2000 to January 2020. Original articles not written in English or Chinese and not available in full-text were excluded. 
medRxiv preprint doi: https://doi.org/10.1101/2020.07.11.20148544; this version posted July 14, 2020. The copyright holder for this preprint (which was not certified by peer review) is the author/funder, who has granted medRxiv a license to display the preprint in perpetuity.

All rights reserved. No reuse allowed without permission.

The following search terms were used individually or combined: "postoperative sore throat"; "intubation complication";"anesthesia complication";"acupressure";"transcutaneous electrical nerve stimulation";"acupuncture";"acupuncture point”;"moxibution";"bloodletting". The MeSH terms were used during the search if the database system was available. Details of the search strategy was shown in Supplementary Table 1.

\section{Study selection}

Two authors selected the included studies according to the eligibility criteria independently. Disagreement was resolved by discussion.

\section{Data extraction}

The same authors examined the included studies and extracted data with a predetermined form. It recorded the first author, year, study design, sample size, sex, age, American Society of Anesthesiologists (ASA) physical status classification, surgery type, intervention, and outcome measurements. Detailed information about the intervention and the anesthesia was also collected.

\section{Risk of bias assessment}


medRxiv preprint doi: https://doi.org/10.1101/2020.07.11.20148544; this version posted July 14, 2020. The copyright holder for this preprint (which was not certified by peer review) is the author/funder, who has granted medRxiv a license to display the preprint in perpetuity.

All rights reserved. No reuse allowed without permission.

The risk of bias was assessed by the same authors independently by using the Cochrane risk of bias assessment tool ${ }^{23}$. To randomized trials, the RoB 2.0 tool was used to assess five domains for risk-of-bias that lead to an overall bias ${ }^{25}$; to non-randomized trials, the ROBINS-I tool was used to assess seven domains that may be ascertained to produce an overall bias ${ }^{26}$. The risk of bias was visualized by robvis ${ }^{27}$. Disagreement was resolved by discussion.

\section{Data synthesis and analysis}

The primary outcome was the incidence or the severity of sore throat at $24 \mathrm{~h}$ after surgery/extubation and adverse events in the study groups. If postoperative sore throat used traditional four-level classification system to rate the severity of the condition (i.e. none, mild, moderate, and severe), the incidence of sore throat was calculated from the sum of mild, moderate, and severe cases. The secondary outcomes included the incidence or the severity of related complications after surgery/extubation. Continuous and dichotomous outcomes were presented as risk ratios (RRs), standardized mean differences (SMDs) and 95\% Cls. When trials contained zero events in either arm, continuity correction was calculated with the addition of 0.5 to each cell of $2 \times 2$ tables from the trial ${ }^{28}$. When continuous outcomes were presented as medians with interquartile range, they were converted to the means and standard deviation via the method proposed by Shi et al. ${ }^{29}$. If the data could not be applied to the meta-analysis, we summarized them in the text. 
medRxiv preprint doi: https://doi.org/10.1101/2020.07.11.20148544; this version posted July 14, 2020. The copyright holder for this preprint (which was not certified by peer review) is the author/funder, who has granted medRxiv a license to display the preprint in perpetuity.

All rights reserved. No reuse allowed without permission.

We chose DerSimonian and Laird random-effects model to analyze collected data. Heterogeneity among studies was assessed using the Higgins I ${ }^{2}$ test; $I{ }^{2}>50 \%$ means substantial heterogeneity. This random-effects model was often considered with inappropriate type I error and we thus conducted sensitivity analysis using Hartung-KnappSidik-Jonkman method because it can work better in a limited number of included studies ${ }^{30}$. Subgroup analyses were also conducted to assess whether the treatment effects were changed because of study design or airway device. Trial sequential analysis was tried to perform due to examine required information size and the reliability of outcome from our meta-analysis. According to the previous review for postoperative complication and acupoint stimulation $^{31}$, we designed a relative risk reduction of $30 \%$ for POST that was considered clinically meaningful in a $5 \%$ risk of a type I error and a power of $80 \%$. Non-randomized studies were excluded from trial sequential analysis. Statistical significance was defined as $p$ $<0.05$, except for the determination of publication bias, that employed $p<0.1$. If more than 10 studies were included in the meta-analysis, publication bias was investigated by funnel plots. Statistical analysis was conducted by Comprehensive Meta-Analysis (CMA), version 3 (Biostat, Englewood, NJ, USA) and the trial sequential analyses were performed using TSA software, version 0.9 beta (Copenhagen Trial Unit, Copenhagen, Denmark). 
medRxiv preprint doi: https://doi.org/10.1101/2020.07.11.20148544; this version posted July 14,2020 . The copyright holder for this preprint (which was not certified by peer review) is the author/funder, who has granted medRxiv a license to display the preprint in perpetuity.

\section{RESULTS}

\section{Overview of included studies}

Our initial search yielded 130 titles and abstracts (Figure 1). After applying the inclusion and exclusion criteria, 3 randomized controlled trials and 1 quasi-experimental study involving 1358 participants were included in the analysis ${ }^{32-35}$. The mean age for the study participants ranged from 35.69 to 48.6 years, and the proportion of women ranged from $35.7 \%$ to $100 \%$ (Table 1). Four trials included patients with an ASA status of I-II. Three trials provided obvious type of surgery, which included total abdominal hysterectomy ${ }^{32}$, cholecystectomy ${ }^{33}$, gastrointestinal ${ }^{33}$, herniorrhaphy ${ }^{33}$, mastectomy ${ }^{33}$, and thyroid surgery ${ }^{33-}$

${ }^{34}$. One trial offered the note that all patients didn't receive head or neck surgery ${ }^{35}$.

One trial used capsicum plaster for acupoint application and compared true-point treatment with sham-point treatment and control ${ }^{32}$. Another trial used plaster with biological wave effect for acupoint application and compared true treatment with control in subgroups divided by the site of acupoint, the position of operation, the type of airway device, and the operation method ${ }^{35}$. The research team firstly tried to compare a 5-acupoints and 2acupoints treatment subgroups with the control subgroup in mode of supine position, normal single lumen, non-laparoscopic surgery, and confirmed the same treatment effect between two acupoint approaches. Other treatment and control subgroups just used 2-acupoints application in other modes. We pooled data from 2-acupoints treatment subgroups in various 
medRxiv preprint doi: https://doi.org/10.1101/2020.07.11.20148544; this version posted July 14, 2020. The copyright holder for this preprint (which was not certified by peer review) is the author/funder, who has granted medRxiv a license to display the preprint in perpetuity.

All rights reserved. No reuse allowed without permission.

mode to analyze because it seemed a major acupoint approach in this trial. The other trial compared the active TENS with the inactive, sham TENS ${ }^{34}$. The quasi-experimental study compared the case of body acupuncture with the case of no acupuncture ${ }^{33}$. The details of the anesthesia and the intervention were summarized in Supplementary Table 2.

One trial used a five-point scale to assess the score of sore throat ${ }^{32}$, and another trial used a visual analog scale (VAS) to assess the score of sore throat ${ }^{34}$. Besides the incidence of postoperative sore throat at $24 \mathrm{~h}$ and the score of sore throat, there were the incidence of postoperative nausea and vomiting at $24 \mathrm{~h}$, the incidence of choking cough and sputum after extubation immediately in outcome which could be available to analyze the effectiveness of acupoint stimulation.

\section{Risk of bias}

The quality of randomized control trials generally needed to have some concerns according to the RoB 2.0 (Figure 2a). Two included studies had unclear random sequence generation and allocation concealment ${ }^{34-35}$; one of them didn't report enough information how to blind when participants received intervention before anesthesia induction ${ }^{34}$. The quality of quasi-experimental study also needed some concerns according to the ROBINSI (Figure 2b). Although all participants in study received tube and had intubation-related 
medRxiv preprint doi: https://doi.org/10.1101/2020.07.11.20148544; this version posted July 14,2020 . The copyright holder for this preprint (which was not certified by peer review) is the author/funder, who has granted medRxiv a license to display the preprint in perpetuity.

trauma, other possible undetermined causes of sore throat could generate confounding factors and could lead to a vague outcome of selection or measurement ${ }^{33}$.

\section{Primary outcomes}

Incidence of postoperative sore throat

Four studies that included 1228 participants provided data on the incidence of sore throat at $24 \mathrm{~h}$ after surgery or extubation $\mathrm{n}^{32-35}$. The resulted indicated that acupoint stimulation was associated with a reduced incidence of postoperative sore throat $(\mathrm{RR}, 0.3 ; 95 \% \mathrm{Cl}, 0.2-$ $0.45 ; p<0.001 ; \mathrm{df}=7 ; R=0 ;$ Figure $3 \mathrm{a})$. The number needed to prevent postoperative sore throat was $6(95 \% \mathrm{Cl}, 6-7)$.

Severity of postoperative sore throat

Two studies involving 121 participants offered the severity of sore throat at $24 \mathrm{~h}$ after surgery or extubation ${ }^{32,34}$. One study assessed the postoperative sore throat at $24 \mathrm{~h}$ with VAS mean score and standard deviation (SD) that had significantly difference between the true treatment and the sham treatment via independent $t$-test ${ }^{34}$; the other reported the sore throat scores at $24 \mathrm{~h}$ with median and range that were significantly lower in the true-point treatment group than sham-point treatment and control via Kruskal-Wallis test ${ }^{32}$. However, by converting median (range) to mean (SD) in math and pooled analyzing, we found that 
medRxiv preprint doi: https://doi.org/10.1101/2020.07.11.20148544; this version posted July 14, 2020. The copyright holder for this preprint (which was not certified by peer review) is the author/funder, who has granted medRxiv a license to display the preprint in perpetuity.

All rights reserved. No reuse allowed without permission.

the acupoint stimulation was associated with decreased severity of postoperative sore throat (SMD, $-2.21 ; 95 \% \mathrm{Cl},-2.67$ to $-1.76 ; p<0.001 ; R=0$; Figure $3 b)$.

Adverse events

One study reported that two patients in the true-point treatment and four patients in the sham-point treatment had the plaster side-effect about mild burning sensation with erythema ${ }^{32}$. The other didn't reported any adverse events developed in their study groups ${ }^{33-}$

\section{Secondary outcomes}

Incidence of postoperative nausea and vomiting

Three studies that included 1128 participants provided data on the incidence of postoperative nausea and vomiting at $24 \mathrm{~h}$ after surgery or extubation ${ }^{32,33,35}$. The trial offered the incidence of nausea and vomiting individually, but we chose the incidence of nausea to analyze because less commonly vomiting occurred without nausea in adult and the proportion of postoperative nausea and vomiting could approximate it ${ }^{32}$. The result showed that the acupoint stimulation was associated with a reduced incidence of postoperative nausea and vomiting $\left(\mathrm{RR}, 0.49 ; 95 \% \mathrm{Cl}, 0.3-0.79 ; p=0.003 ; \mathrm{df}=6 ; R^{2}=0 ;\right.$ Figure $\left.4 \mathrm{a}\right)$. 
medRxiv preprint doi: https://doi.org/10.1101/2020.07.11.20148544; this version posted July 14, 2020. The copyright holder for this preprint (which was not certified by peer review) is the author/funder, who has granted medRxiv a license to display the preprint in perpetuity.

All rights reserved. No reuse allowed without permission.

The studies with 800 participants provided data on the incidence of choking cough and sputum immediately after extubation ${ }^{35}$. The acupoint stimulation was associated with a reduced incidence of choking cough $(\mathrm{RR}, 0.19 ; 95 \% \mathrm{Cl}, 0.15-0.25 ; p<0.001 ; \mathrm{df}=4 ; R=0$; Figure 4b) and a reduced incidence of sputum (RR, 0.29;95\% $\mathrm{Cl}, 0.22-0.38 ; p<0.001$; $\mathrm{df}=4 ; R=0 ;$ Figure $4 \mathrm{c})$.

\section{Subgroup, sensitivity, and trial sequential analyses}

In subgroup analysis, for study design, we divided four studies into RCT and QES group. It was no significant difference between two groups ( $Q$-value, 3.099; $p=0.078 ; \mathrm{df}=1$ ), but pooled analysis with only RCT group could show more reduced incidence of POST (RR, $0.25 ; 95 \% \mathrm{Cl}, 0.16-0.39 ; p<0.001)$. For airway device, we inferred that three studies used single lumen tube from the description of anesthesia process, tube size and surgery type in the articles ${ }^{32-34}$, and divided four studies into single lumen, double lumen, and laryngeal mask group. There was no significant difference among three groups (Q-value, 3.35; $p=0.187 ; \mathrm{df}=2$ ) and all tended to favor acupoint stimulation for reducing the incidence of POST.

We conducted sensitivity analysis on the incidence of POST, PONV, choking cough and sputum via Hartung-Knapp-Sidik-Jonkman method. The aggregate effect in each outcome was consistent with the primary finding and all were still statistically significant despite becoming larger range of $95 \% \mathrm{CI}$ (Supplementary Table 3). When excluding QES, 
medRxiv preprint doi: https://doi.org/10.1101/2020.07.11.20148544; this version posted July 14,2020 . The copyright holder for this preprint (which was not certified by peer review) is the author/funder, who has granted medRxiv a license to display the preprint in perpetuity.

All rights reserved. No reuse allowed without permission.

trial sequential analysis with RCTs suggested that the cumulative z-curve crossed both the conventional and trial sequential monitoring boundaries for benefit before reaching the required information size (1602 patients), thereby recommending a positive effect of acupoint stimulation on the prevention of postoperative sore throat (Supplementary Figure 1). 
medRxiv preprint doi: https://doi.org/10.1101/2020.07.11.20148544; this version posted July 14, 2020. The copyright holder for this preprint (which was not certified by peer review) is the author/funder, who has granted medRxiv a license to display the preprint in perpetuity.

All rights reserved. No reuse allowed without permission.

\section{DISCUSSION}

According to limited data derived from the included trials, our study suggests that acupoint stimulation in adults undergoing tracheal intubation for surgery under general anesthesia is associated with a decline of POST at $24 \mathrm{~h}$ and possibly results in less severity in comparison with non- / sham- acupoint stimulation. It seems a good prophylactic effect that the number needed to prevent postoperative sore throat is 6 . A decline of PONV in our study is consistent with the current evidence-based article ${ }^{31}$. Both of decline of choking cough and sputum in our study also provide the likely positive effect when facing complications related to the removal of airway device. Limited evidence suggests that acupoint stimulation is not related with significant negative-events. Although we are not able to collect studying samples with the best quality for meta-analysis, our findings are robust throughout subgroup, sensitivity, and trial sequential analyses, thereby confirming that acupoint stimulation prevents postoperative sore throat.

As normal, the number of patients with POST decrease within $48 \mathrm{~h}$ and a few patients still have symptom at $96 \mathrm{~h}^{8}$. To improve POST, most current medications are assessed via the incidence / severity of POST at $24 \mathrm{~h}^{12-17}$. The possible mechanisms of medications to prevent or treat POST are anti-inflammatory effect, sensory-nerves suppression, and Nmethyl-D-aspartic acid (NMDA) receptor antagonists ${ }^{12-17}$. In our view, the possible mechanisms of acupoint stimulation to prevent or treat POST are two proposed possibilities. 
medRxiv preprint doi: https://doi.org/10.1101/2020.07.11.20148544; this version posted July 14, 2020. The copyright holder for this preprint (which was not certified by peer review) is the author/funder, who has granted medRxiv a license to display the preprint in perpetuity.

All rights reserved. No reuse allowed without permission.

One is to regulate anti-inflammatory response, increase local blood circulation and reduce reginal inflammatory-related pain ${ }^{36-37}$. The other is to start the neurophysiological system and induce acupuncture-analgesic effect ${ }^{38}$.

Although the clinical application of acupoint stimulation in POST remains less, previous reviews in related fields are encouraging. Lu et al. ${ }^{39}$ suggests that the perioperative period under anesthesia combined with acupuncture might be benefit to patients with less analgesic consumption, lower incidence of complications and better recovery; the article also gives some indications, such as appropriate acupoints selection, electric stimulation with better analgesia, and targeted population. Yoo et al. ${ }^{40}$ shows that enhanced recovery in gynecological surgery with acupuncture improves gastrointestinal motility, coldness, PONV, sore throat, and urinary retention. ERAS pathways still require multimodal analgesia to reduce pain, improve analgesic-related adverse effects and accelerate postsurgical recovery ${ }^{41}$. Acupoint stimulation by acupuncture and related techniques seems to be an effective, nonpharmacological approach with better safety and less cost in favor of ERAS ${ }^{20,}$ 39, 42-43. Yuan et al. ${ }^{44}$ also proposes the concept of "perioperative acupuncture medicine", which is the intervention of acupuncture or related techniques with acupoint stimulation before, during and after surgery, and hopefully it could be developed within ERAS.

There are a few limitations in this review. Firstly, we enroll non- / low-quality 
medRxiv preprint doi: https://doi.org/10.1101/2020.07.11.20148544; this version posted July 14,2020 . The copyright holder for this preprint (which was not certified by peer review) is the author/funder, who has granted medRxiv a license to display the preprint in perpetuity.

All rights reserved. No reuse allowed without permission.

randomized trials to analyze and they limit the strength of our findings. Secondly, there is not enough sample size to decide the effectiveness of our finding. Thirdly, only one study mentions adverse events. Finally, our search is limited to English and Chinese articles only, causing a potential language bias.

In summary, true treatment with acupoints stimulation is significantly more effective than non- /sham- treatment for the prevention of postoperative sore throat at $24 \mathrm{~h}$. Our finding also shows more positive result about POVN, choking cough, and sputum when stimulating acupoints. Acupoints stimulation could be considered as one of nonpharmacological ways to prevent POST in ERAS. However, it still needs further clinical trials to determine the effectiveness of acupoint stimulation and adverse events due to lack of low bias risk and high-quality studies. 
medRxiv preprint doi: https://doi.org/10.1101/2020.07.11.20148544; this version posted July 14,2020 . The copyright holder for this preprint (which was not certified by peer review) is the author/funder, who has granted medRxiv a license to display the preprint in perpetuity.

\section{REFERENCES}

1. McHardy FE, Chung F. Postoperative sore throat: cause, prevention and treatment. Anaesthesia. 1999;54(5):444-453.

2. Lee JY, Sim WS, Kim ES, et al. Incidence and risk factors of postoperative sore throat after endotracheal intubation in Korean patients. J Int Med Res. 2017;45(2):744-752.

3. Shrestha S, Maharjan B, Karmacharya RM. Incidence and Associated Risk Factors of Postoperative Sore Throat in Tertiary Care Hospital. Kathmandu Univ Med J (KUMJ). 2017;15(57):10-13.

4. Piriyapatsom A, Dej-Arkom S, Chinachoti T, Rakkarnngan J, Srishewachart P. Postoperative sore throat: incidence, risk factors, and outcome. J Med Assoc Thai. 2013;96(8):936-942.

5. Lehmann M, Monte K, Barach P, Kindler CH. Postoperative patient complaints: a prospective interview study of 12,276 patients. J Clin Anesth. 2010;22(1):13-21.

6. Moningi S, Patki A, Padhy N, Ramachandran G. Enhanced recovery after surgery: An anesthesiologist's perspective. J Anaesthesiol Clin Pharmacol. 2019;35(Suppl 1):S5S13.

7. Tong D, Chung F, Wong D. Predictive factors in global and anesthesia satisfaction in ambulatory surgical patients. Anesthesiology. 1997;87(4):856-864.

8. Jaensson M, Gupta A, Nilsson U. Gender differences in sore throat and hoarseness following endotracheal tube or laryngeal mask airway: a prospective study. BMC 
medRxiv preprint doi: https://doi.org/10.1101/2020.07.11.20148544; this version posted July 14, 2020. The copyright holder for this preprint (which was not certified by peer review) is the author/funder, who has granted medRxiv a license to display the preprint in perpetuity.

Anesthesiol. 2014;14:56.

9. Flexman AM, Duggan LV. Postoperative sore throat: inevitable side effect or preventable nuisance? Can J Anaesth. 2019;66(9):1009-1013.

10. Chandler M. Tracheal intubation and sore throat: a mechanical explanation. Anaesthesia. 2002;57(2):155-161.

11. Combes X, Schauvliege F, Peyrouset $O$, et al. Intracuff pressure and tracheal morbidity: influence of filling with saline during nitrous oxide anesthesia. Anesthesiology. 2001;95(5):1120-1124.

12. Kuriyama A, Maeda H. Preoperative intravenous dexamethasone prevents tracheal intubation-related sore throat in adult surgical patients: a systematic review and metaanalysis. Can J Anaesth. 2019;66(5):562-575.

13. Kuriyama A, Aga M, Maeda H. Topical benzydamine hydrochloride for prevention of postoperative sore throat in adults undergoing tracheal intubation for elective surgery: a systematic review and meta-analysis. Anaesthesia. 2018;73(7):889-900.

14. Kuriyama A, Maeda H, Sun R, Aga M. Topical application of corticosteroids to tracheal tubes to prevent postoperative sore throat in adults undergoing tracheal intubation: a systematic review and meta-analysis. Anaesthesia. 2018;73(12):1546-1556.

15. Yang SS, Wang N-N, Postonogova T, et al. Intravenous lidocaine to prevent postoperative airway complications in adults: a systematic review and meta-analysis. Br J Anaesth. 2020;124(3):314-323. 
medRxiv preprint doi: https://doi.org/10.1101/2020.07.11.20148544; this version posted July 14, 2020. The copyright holder for this preprint (which was not certified by peer review) is the author/funder, who has granted medRxiv a license to display the preprint in perpetuity. All rights reserved. No reuse allowed without permission.

16. Kuriyama A, Nakanishi M, Kamei J, Sun R, Ninomiya K, Hino M. Topical application of ketamine to prevent postoperative sore throat in adults: A systematic review and metaanalysis. Acta Anaesthesiol Scand. 2020;64(5):579-591.

17. Kuriyama A, Maeda H, Sun R. Topical application of magnesium to prevent intubationrelated sore throat in adult surgical patients: a systematic review and meta-analysis. Can J Anaesth. 2019;66(9):1082-1094.

18. Wu M-S, Chen K-H, Chen I-F, et al. The Efficacy of Acupuncture in Post-Operative Pain Management: A Systematic Review and Meta-Analysis. PLoS ONE. 2016;11(3):e0150367.

19. Tan H, Tumilty S, Chapple C, et al. Understanding Acupoint Sensitization: A Narrative Review on Phenomena, Potential Mechanism, and Clinical Application. Evid Based Complement Alternat Med. 2019; 2019:6064358.

20. Chernyak GV, Sessler DI. Perioperative acupuncture and related techniques. Anesthesiology. 2005;102(5):1031-1049; quiz 1077-1078.

21. Jun M-H, Kim Y-M, Kim JU. Modern acupuncture-like stimulation methods: a literature review. Integr Med Res. 2015;4(4):195-219.

22. Ivanov A. The Analogy Between the Tradition Chinese Acupuncture and Phlebotomy in Medieval Bohemia. J Acupunct Meridian Stud. 2019;12(4):136-144.

23. Higgins JPT, Thomas J, Chandler J, et al. Cochrane Handbook for Systematic Reviews of Interventions. John Wiley \& Sons; 2019. 
medRxiv preprint doi: https://doi.org/10.1101/2020.07.11.20148544; this version posted July 14, 2020. The copyright holder for this preprint (which was not certified by peer review) is the author/funder, who has granted medRxiv a license to display the preprint in perpetuity. All rights reserved. No reuse allowed without permission.

24. Moher D, Liberati A, Tetzlaff J, Altman DG, Group TP. Preferred Reporting Items for Systematic Reviews and Meta-Analyses: The PRISMA Statement. PLOS Medicine. 2009;6(7):e1000097.

25. Sterne JAC, Savović J, Page MJ, et al. RoB 2: a revised tool for assessing risk of bias in randomised trials. BMJ. 2019;366:14898.

26. Sterne JA, Hernán MA, Reeves BC, et al. ROBINS-I: a tool for assessing risk of bias in non-randomised studies of interventions. BMJ. 2016;355: i4919.

27. McGuinness LA. robvis: An R package and web application for visualising risk-of-bias assessments. https://github.com/mcguinlu/robvis. Published July 1, 2019.

28. Sweeting MJ, Sutton AJ, Lambert PC. What to add to nothing? Use and avoidance of continuity corrections in meta-analysis of sparse data. Stat Med. 2004;23(9):13511375.

29. Shi J, Luo D, Weng $H$, et al. Optimally estimating the sample mean and standard deviation from the five-number summary. arXiv:200302130 [stat]. March 2020. http://arxiv.org/abs/2003.02130. Accessed April 27, 2020.

30. Röver C, Knapp G, Friede T. Hartung-Knapp-Sidik-Jonkman approach and its modification for random-effects meta-analysis with few studies. BMC Medical Research Methodology. 2015;15(1):99. 
medRxiv preprint doi: https://doi.org/10.1101/2020.07.11.20148544; this version posted July 14, 2020. The copyright holder for this preprint (which was not certified by peer review) is the author/funder, who has granted medRxiv a license to display the preprint in perpetuity.

All rights reserved. No reuse allowed without permission.

31. Lee A, Chan SKC, Fan LTY. Stimulation of the wrist acupuncture point PC6 for preventing postoperative nausea and vomiting. Cochrane Database Syst Rev. 2015;(11):CD003281.

32. Park HS, Kim KS, Min HK, Kim DW. Prevention of postoperative sore throat using capsicum plaster applied at the Korean hand acupuncture point. Anaesthesia. 2004;59(7):647-651.

33. Esmaeili S, Alizadeh R, Shoar S, Naderan M, Shoar N. Acupuncture in preventing postoperative anaesthesia-related sore throat: a comparison with no acupuncture. Acupunct Med. 2013;31(3):272-275.

34. Wang D-D, Ma T-T, Li G-Z, Fan S-S. Effects of transcutaneous electrical acupoint stimulation on treatment and prevention of postoperative sore throat after tracheal intubation under general anesthesia. Chinese acupuncture \& moxibustion. 2017;37(7):701-704.

35. Lu X-H, Zhang X-M, Liu S-L, et al. Clinical Research on Prevention and Treatment of Respiratory Tract Complications With Acupoint Application After Operation Under General Anesthesia. J Craniofac Surg. 2019;30(1):e85-e92.

36. McDonald JL, Cripps AW, Smith PK, Smith CA, Xue CC, Golianu B. The antiinflammatory effects of acupuncture and their relevance to allergic rhinitis: a narrative review and proposed model. Evid Based Complement Alternat Med. 2013; 2013:591796. 
medRxiv preprint doi: https://doi.org/10.1101/2020.07.11.20148544; this version posted July 14, 2020. The copyright holder for this preprint (which was not certified by peer review) is the author/funder, who has granted medRxiv a license to display the preprint in perpetuity. All rights reserved. No reuse allowed without permission.

37. Tsuchiya M, Sato EF, Inoue M, Asada A. Acupuncture enhances generation of nitric oxide and increases local circulation. Anesth Analg. 2007;104(2):301-307.

38. Leung L. Neurophysiological Basis of Acupuncture-induced Analgesia-An Updated Review. Journal of Acupuncture and Meridian Studies. 2012;5(6):261-270.

39. Lu Z, Dong H, Wang Q, Xiong L. Perioperative acupuncture modulation: more than anaesthesia. Br J Anaesth. 2015;115(2):183-193.

40. Yoo J-E, Oh D-S. Potential benefits of acupuncture for enhanced recovery in gynaecological surgery. Forsch Komplementmed. 2015;22(2):111-116.

41. Kaye AD, Granier AL, Garcia AJ, et al. Non-Opioid Perioperative Pain Strategies for the Clinician: A Narrative Review. Pain Ther. 2020;9(1):25-39.

42. Liu X-L, Tan J-Y, Molassiotis A, Suen LKP, Shi Y. Acupuncture-Point Stimulation for Postoperative Pain Control: A Systematic Review and Meta-Analysis of Randomized Controlled Trials. Evid Based Complement Alternat Med. 2015;2015:657809.

43. Fan AY, Miller DW, Bolash B, et al. Acupuncture's Role in Solving the Opioid Epidemic: Evidence, Cost-Effectiveness, and Care Availability for Acupuncture as a Primary, Non-Pharmacologic Method for Pain Relief and Management-White Paper 2017. J Integr Med. 2017;15(6):411-425.

44. Yuan W, Wang Q. Perioperative acupuncture medicine: a novel concept instead of acupuncture anesthesia. Chin Med J. 2019;132(6):707-715. 
medRxiv preprint doi: https://doi.org/10.1101/2020.07.11.20148544; this version posted July 14, 2020. The copyright holder for this preprint (which was not certified by peer review) is the author/funder, who has granted medRxiv a license to display the preprint in perpetuity.

Table 1. Characteristics of included studies.

Figure 1. PRISMA flow diagram for searching and identification of included studies.

Figure 2. Risk of bias summery for included studies. (a) 3 RCT via RoB 2.0; (b)1 QES via ROBINS-I. RCT: randomized controlled trial; QES: quasi-experimental study.

Figure 3. The forest plot presented (a) the incidence and (b) the severity of postoperative sore throat at $24 \mathrm{~h}$ in patients who received the intervention between point stimulation and none / sham point stimulation. $\quad$ NSL: normal single lumen; SSL: spring single lumen; DL: double lumen; LMAS: laryngeal mask; PP: prone position, SP: supine position; LD: lateral decubitus; LS /non-LS: laparoscopic surgery / non- laparoscopic surgery

Figure 4. The forest plot presented the incidence of (a) postoperative nausea and vomiting at $24 \mathrm{~h}$ and the incidence of (b) choking cough, (c) sputum immediately after exbutaion in patients who received the intervention between point stimulation and none / sham point stimulation. $\quad$ NSL: normal single lumen; SSL: spring single lumen; DL: double lumen; LMAS: laryngeal mask; PP: prone position, SP: supine position; LD: lateral decubitus; LS /non-LS: laparoscopic surgery / non- laparoscopic surgery

Supplemental Table 1. Table that demonstrates the search strategy. 
medRxiv preprint doi: https://doi.org/10.1101/2020.07.11.20148544; this version posted July 14,2020 . The copyright holder for this preprint (which was not certified by peer review) is the author/funder, who has granted medRxiv a license to display the preprint in perpetuity.

All rights reserved. No reuse allowed without permission.

Supplemental Table 2. Table that presents the detail information of anesthesia and intervention.

Supplemental Table 3. Table that demonstrates the sensitivity analysis via HartungKnapp-Sidik-Jonkman method.

Supplemental Figure 1. Figure that demonstrates the trial sequential analysis with median control event proportion of $16 \%$. 
Table 1. Characteristics of included studies.

\begin{tabular}{|c|c|c|c|c|c|c|c|}
\hline $\begin{array}{l}\text { First author } \\
\text { (year) }\end{array}$ & $\begin{array}{l}\text { Study } \\
\text { design }\end{array}$ & $\begin{array}{l}\text { Sample size }(\% \\
\text { female) }\end{array}$ & $\begin{array}{l}\text { Mean age (SD or } \\
\text { range) }\end{array}$ & ASA & Surgery & Intervention & Outcome measurement \\
\hline $\begin{array}{l}\text { Park et al. }{ }^{32} \\
(2004)\end{array}$ & $\mathrm{RCT}$ & $\begin{array}{l}\text { True T: } 50(100 \%) \\
\text { Sham T: } 50(100 \%) \\
\text { C: } 50(100 \%)\end{array}$ & $\begin{array}{l}\text { True T: } 43.8(32-59) \\
\text { Sham T: } 44.9(33-61) \\
\text { C: } 42.6(32-47)\end{array}$ & I, II & $\begin{array}{l}\text { Total abdominal } \\
\text { hysterectomy }\end{array}$ & $\begin{array}{l}\text { Capsicum plasters were applied on bilateral K-A20 points } \\
\text { but placebo tape on bilateral thighs. (true treatment) } \\
\text { Plasters on bilateral thighs but tapes on K-A20 points. } \\
\text { (sham treatment) } \\
\text { Placebo tapes were applied on all sites. (control) }\end{array}$ & $\begin{array}{l}\text { Incidence of POST and sore throat } \\
\text { score at recovery room, at } 24 \mathrm{~h} \\
\text { Incidence of PONV and dosage of } \\
\text { analgesic, at } 24 \mathrm{~h}\end{array}$ \\
\hline $\begin{array}{l}\text { Esmaeili et al. }{ }^{33} \\
(2013)\end{array}$ & QES & $\begin{array}{l}\text { T: } 114(33.3 \%) \\
\text { C: } 114(38.6 \%)\end{array}$ & $\begin{array}{l}\text { T: } 40.54( \pm 14.1) \\
\text { C: } 35.69( \pm 13.22)\end{array}$ & I, II & $\begin{array}{l}\text { About cholecystectomy, } \\
\text { gastrointestinal, thyroid, } \\
\text { herniorrhaphy, and } \\
\text { mastectomy }\end{array}$ & $\begin{array}{l}\text { Acupuncture with needle was manipulated on bilateral PC6 } \\
\text { points. (treatment) } \\
\text { No acupuncture. (control) }\end{array}$ & $\begin{array}{l}\text { Incidence of fever, bleeding, PONV, } \\
\text { POST, ICU admission, sore throat } \\
\text { needing medical care, at } 24 \mathrm{~h}\end{array}$ \\
\hline $\begin{array}{l}\text { Wang et al. } .^{34} \\
(2017)\end{array}$ & $\mathrm{RCT}$ & $\begin{array}{l}\text { T: } 50(78 \%) \\
\text { C: } 50(84 \%)\end{array}$ & $\begin{array}{l}\text { T: } 44( \pm 10) \\
\text { C: } 42( \pm 9)\end{array}$ & I, II & Thyroid gland lobectomy & $\begin{array}{l}\text { TEAS was activated on bilateral LI4 and PC6 points. } \\
\text { (treatment) } \\
\text { TEAS was not activated on the same points. (control) }\end{array}$ & $\begin{array}{l}\text { Incidence of POST, at } 1 \mathrm{~h}, 6 \mathrm{~h}, 12 \mathrm{~h}, 24 \mathrm{~h} \\
\text { Sore throat VAS, at } 1 \mathrm{~h}, 6 \mathrm{~h}, 12 \mathrm{~h}, 24 \mathrm{~h}\end{array}$ \\
\hline $\begin{array}{l}\text { Lu et al }{ }^{35} \\
(2019)\end{array}$ & $\mathrm{RCT}$ & $\begin{array}{l}\text { T: } 480(50.8 \%) \\
\text { C: } 400(35.7 \%)\end{array}$ & $\begin{array}{l}\mathrm{T}: 48.6( \pm 12.9) \\
\mathrm{C}: 47.1( \pm 11.1)\end{array}$ & I, II & $\begin{array}{l}\text { All possible surgeries } \\
\text { except head and neck }\end{array}$ & $\begin{array}{l}\text { Treatment plasters with biological wave effect were applied } \\
\text { on RN22 and RN23 points in five subgroups (SP, NSL, } \\
\text { non-LS; PP, SSL, non-LS; SP, NSL, LS; SP, LMAS, } \\
\text { non-LS; LD, DL, non-LS). (treatment) } \\
\text { Blank tape were applied on the same points and in other } \\
\text { five subgroups. (control) }\end{array}$ & $\begin{array}{l}\text { Incidence of choking cough and } \\
\text { sputum, after extubation immediately } \\
\text { Score of choking cough, amount of } \\
\text { sputum, pH value of sputum } \\
\text { Incidence of POST, at the time of } \\
\text { leaving PACU and } 24 \mathrm{~h} \\
\text { Incidence of POVN, at } 24 \mathrm{~h}\end{array}$ \\
\hline
\end{tabular}

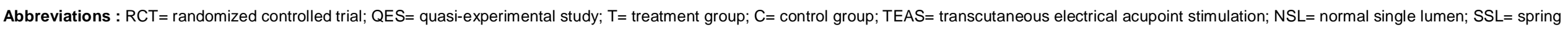

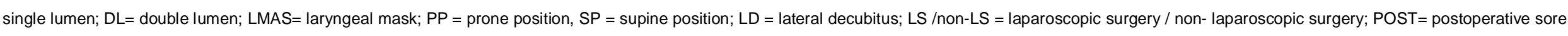
throat; PONV= postoperative nausea and vomiting; VAS= Visual Analogue Scale; ICU=Intensive Care Unit; PACU=post-anesthesia care unit 
Records identified through

PubMed, Cochrane, ScienceDirect searching $(n=125)$
Additional records identified through ClinicalTrail.gov

$$
(n=5)
$$

Records identified $(n=130)$

Duplicated records excluded $(n=14)$

Records after duplicates removed $(n=116)$

\section{Full-text articles assessed}

for eligibility $(n=4)$

Studies included in qualitative synthesis $(n=4)$

Studies included in meta-analysis $(n=4)$ 
a.

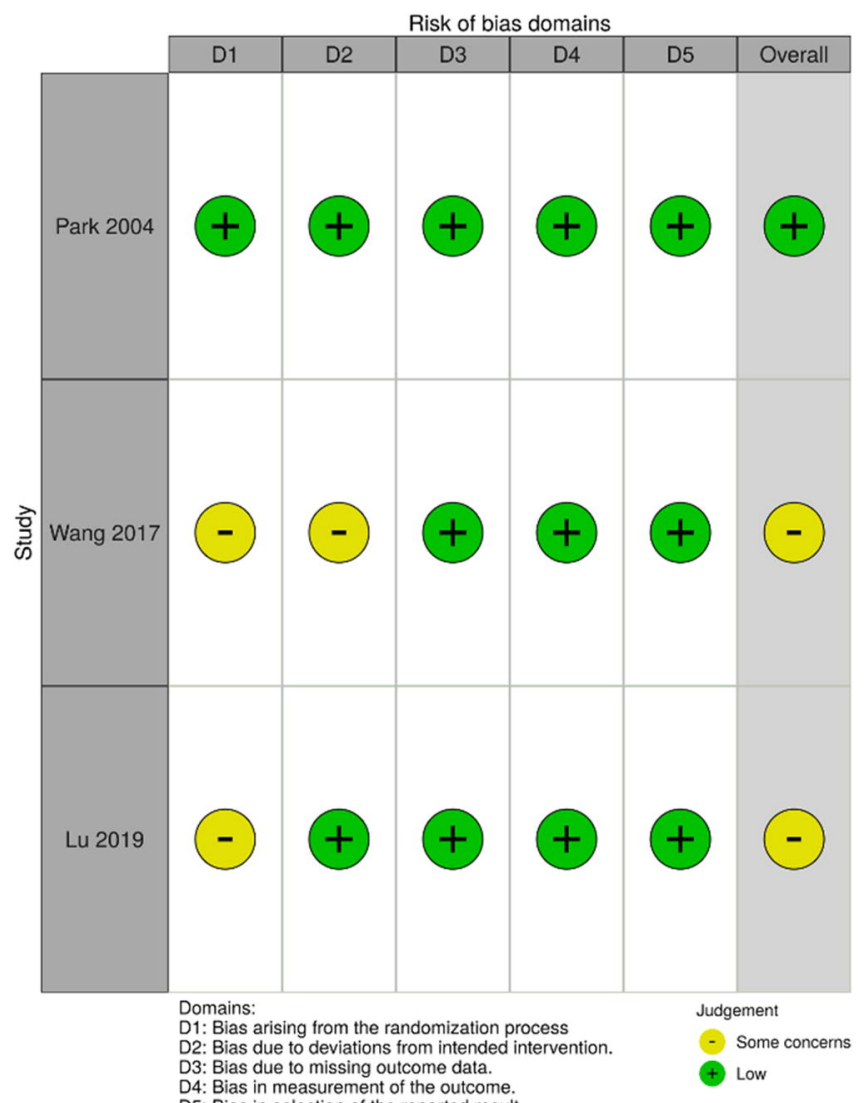

b.

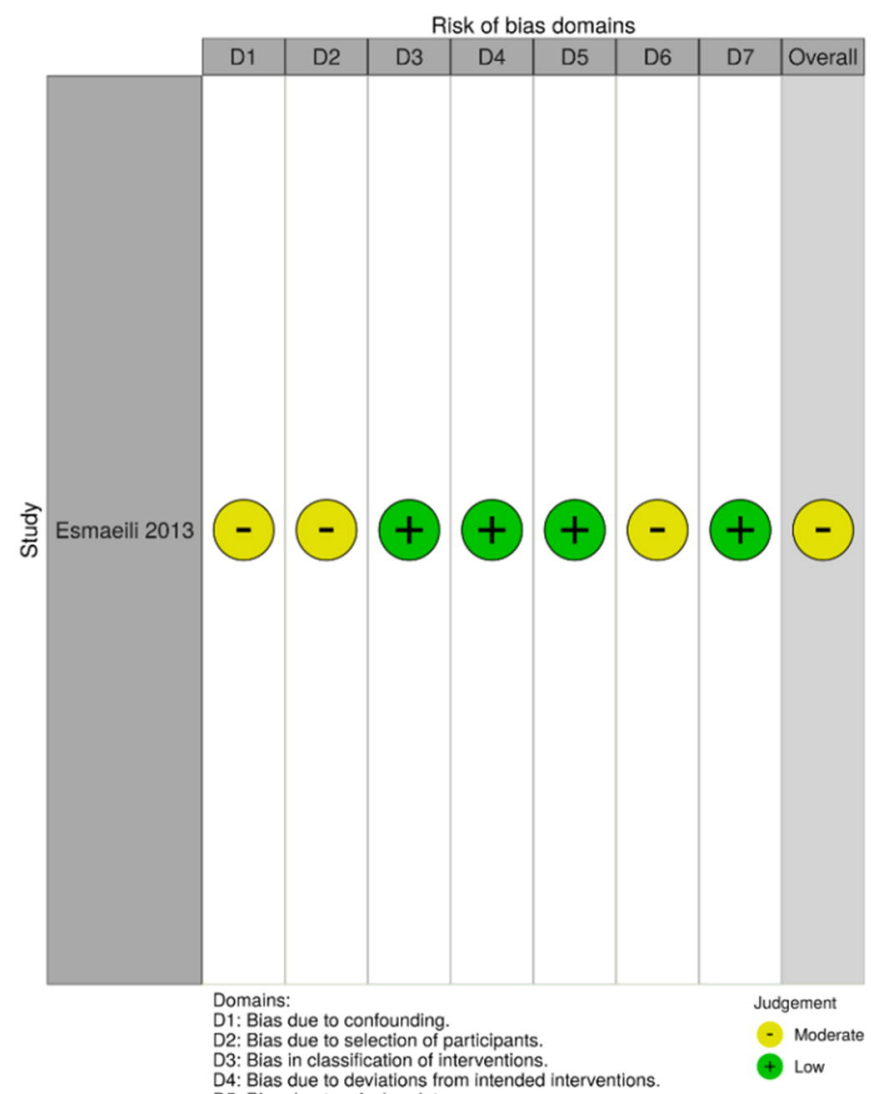

D4: Bias due to deviations from intended interventions. D5: Bias due to missing data.

D6: Bias in measurement of outcomes. 
a.

\begin{tabular}{llcccc} 
Study name & Subgroup & & \multicolumn{3}{c}{ Statistics for each study } \\
\cline { 3 - 6 } & & & $\begin{array}{c}\text { Risk } \\
\text { ratio }\end{array}$ & $\begin{array}{c}\text { Lower } \\
\text { limit }\end{array}$ & $\begin{array}{c}\text { Upper } \\
\text { limit }\end{array}$ \\
Park 2004 & N/A & 0.06 & 0.00 & 0.99 \\
Esmaeili 2013 & N/A & 0.47 & 0.28 & 0.80 \\
Wang 2017 & N/A & 0.50 & 0.22 & 1.13 \\
Lu 2019 & LD, DL, non-LS & 0.17 & 0.07 & 0.42 \\
Lu 2019 & PP, SSL, non-LS & 0.23 & 0.07 & 0.78 \\
Lu 2019 & SP, LMAS, non-LS & 0.12 & 0.02 & 0.85 \\
Lu 2019 & SP, NSL, LS & 0.29 & 0.10 & 0.83 \\
Lu 2019 & SP, NSL, non-LS & 0.15 & 0.04 & 0.66 \\
& & 0.30 & 0.20 & 0.45
\end{tabular}

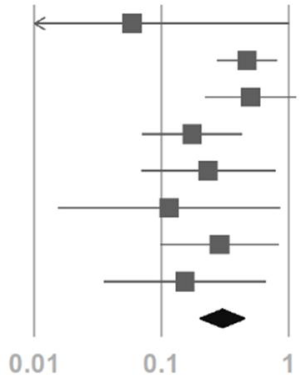

Acupoint stimulation
Relative weight

2.01 31.39 18.16 15.90 9.70 3.87 11.97 7.00

b.

\begin{tabular}{llccc} 
Study name & Subgroup & \multicolumn{3}{c}{ Statistics for each study } \\
\cline { 3 - 6 } & & $\begin{array}{c}\text { Std diff } \\
\text { in means }\end{array}$ & $\begin{array}{c}\text { Lower } \\
\text { limit }\end{array}$ & $\begin{array}{c}\text { Upper } \\
\text { limit }\end{array}$ \\
Park 2004 & N/A & -2.30 & -2.81 & -1.80 \\
Wang 2017 & N/A & -1.82 & -2.88 & -0.76 \\
& & -2.21 & -2.67 & -1.76
\end{tabular}

\section{Std diff in means and $95 \% \mathrm{CI}$}
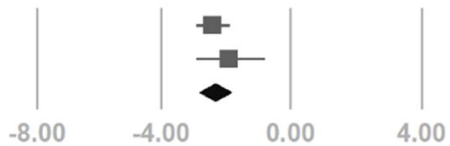

Relative weight

81.51 18.49 
a.

\begin{tabular}{llrrc} 
Study name & Subgroup & \multicolumn{3}{c}{ Statistics for each study } \\
\cline { 3 - 6 } & & $\begin{array}{c}\text { Risk } \\
\text { ratio }\end{array}$ & $\begin{array}{c}\text { Lower } \\
\text { limit }\end{array}$ & $\begin{array}{c}\text { Upper } \\
\text { limit }\end{array}$ \\
Park 2004 & N/A & 0.94 & 0.70 & 1.26 \\
Esmaeili 2013 & N/A & 1.07 & 0.82 & 1.40 \\
Lu 2019 & LD, DL, non-LS & 0.42 & 0.20 & 0.91 \\
Lu 2019 & PP, SSL, non-LS & 0.37 & 0.16 & 0.83 \\
Lu 2019 & SP, LMAS, non-LS & 0.30 & 0.13 & 0.71 \\
Lu 2019 & SP, NSL, LS & 0.26 & 0.14 & 0.49 \\
Lu 2019 & SP, NSL, non-LS & 0.30 & 0.13 & 0.71 \\
& & 0.49 & 0.30 & 0.79
\end{tabular}

Statistics for each study

\section{Risk Lower Upper} ratio limit limit

Lu 2019

Lu 2019

Lu 2019

Lu 2019

Lu 2019

\section{Subgroup}

LD, DL, non-LS

PP, SSL, non-LS

SP, LMAS, non-LS

$S P, N S L, L S$

SP, NSL, non-LS
0.19

0.11

0.33

0.20

0.13

0.32

0.16

0.07

0.39

0.22

0.13

0.36

0.16

0.09

0.31

0.19

0.15

0.25
Statistics for each study

$\begin{array}{ccc}\text { Risk } & \text { Lower } & \text { Upper } \\ \text { ratio } & \text { limit } & \text { limit }\end{array}$

LD, DL, non-LS

0.27

0.31

0.17

0.17

0.44

PP, SSL, non-LS

0.27

0.12

0.57

SP, LMAS, non-LS

0.30

0.16

0.58

SP, NSL, LS

0.57

SP, NSL, non-LS
0.14

0.28

0.22

\section{Risk ratio and $95 \% \mathrm{Cl}$}

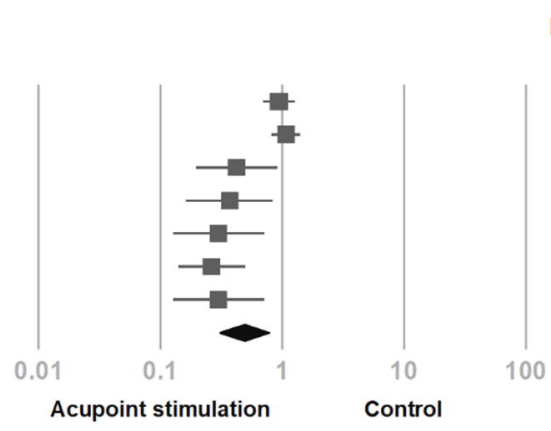

Relative weight

18.06

18.30

12.91

12.42

11.89

14.54

11.89

\section{Risk ratio and $95 \% \mathrm{Cl}$}

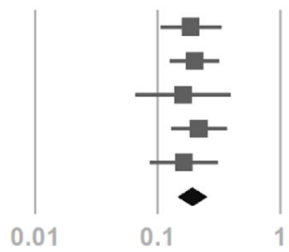

Acupoint stimulation

Control

\section{Relative} weight

20.37

30.69

8.14

24.61

16.18

\section{Risk ratio and $95 \% \mathrm{Cl}$}

Relative weight

32.31

20.47

12.37

18.37

16.48

$\begin{array}{lll}0.29 & 0.22 & 0.38\end{array}$
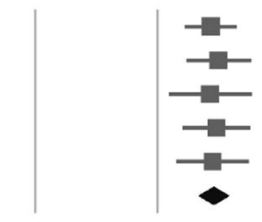

0.1

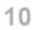

Control 